\title{
STUDENTS PERCEPTION ON IMPLEMENTATION OF INTERPROFESSIONAL EDUCATION
}

\author{
Multazam Fahreza Chandra ${ }^{1 *}$, Laila Isrona ${ }^{2}$, Emilzon Taslim ${ }^{3}$, Ilmiawati $^{4}$ \\ ${ }^{1}$ Program Studi Kedokteran, Fakultas Kedokteran Universitas Andalas, Padang - INDONESIA \\ ${ }^{2}$ Bagian Pendidikan Kedokteran, Fakultas Kedokteran Universitas Andalas, Padang - INDONESIA \\ ${ }^{3}$ Bagian Anestesiologi, Fakultas Kedokteran Universitas Andalas/RSUP Dr. M. Djamil, Padang - INDONESIA \\ ${ }^{4}$ Bagian Farmakologi Klinik, Fakultas Kedokteran Universitas Andalas, Padang - INDONESIA \\ Submitted: 06 Sep 2020; Final Revision from Authors: 22 Feb 2021; Accepted: 15 Mar 2021
}

\begin{abstract}
Background: Collaboration between health professionals is needed to improve health services. The collaboration can be applied to the education system through the Interprofessional Education (IPE) concept. This study aimed to examine students' perception on the IPE implementation.
\end{abstract}

Methods: This was a descriptive study using cross-sectional method. The study sample were 300 undergraduate students in Medical Faculty Andalas University (MFAU). It consisted of 190 medical students, 72 psychology students, and 38 midwifery students. The sample was determined by proportionate stratified random sampling method. The research instrument used was Interdisciplinary Education Perception Scale (IEPS) questionnaire.

Results: The 52 students (84\%) howed positive perception on IPE implementation. The highest percentage (90\%) of the component of perception was actual cooperation and the component of understanding of others' profession had the lowest percentage (51\%). Midwifery students had the highest percentage of perception (92.1\%), while the lowest percentage of perception was showed by psychology students (72.2\%). The perception tended to increase in perception from first-year (85.7\%) to second-year (89.9\%) and declined in third-year students (76\%).

Conclusion: Students of MFAU havinga good perception on the IPE implementation. However, there is a lack of understanding of others' profession that needs to be addressed and improved.

Keywords: collaboration, interprofessional education, perception, students

\section{ABSTRAK}

Latar belakang: Kolaborasi antar profesi kesehatan diperlukan untuk meningkatkan pelayanan kesehatan. Kolaborasi diterapkan pada sistem pendidikan melalui Interprofessional Education (IPE). Penelitian ini bertujuan untuk mengetahui persepsi mahasiswa terhadap implementasi IPE.

Metode: Penelitian ini merupakan penelitian deskriptif menggunakan rancangan cross-sectional. Sampel penelitian adalah 300 mahasiswa yang terdiri atas 190 mahasiswa S1 Kedokteran, 72 mahasiswa Psikologi, dan 38 mahasiswa Kebidanan. Sampel penelitian ditentukan dengan metode proportionate stratified random sampling. Penelitian menggunakan kuesioner Interdisciplinary Education Perception Scale (IEPS).

Hasil: Sebanyak 252 mahasiswa (84\%) memiliki persepsi yang baik terhadap implementasi IPE dengan komponen bukti bekerja sama memiliki persentase tertinggi (90\%) dan komponen pemahaman mengenai profesi lain memiliki persentase terendah (51\%). Mahasiswa Kebidanan memiliki persentase persepsi tertinggi

$\overline{\text { *corresponding author, contact: multazamfahreza12@gmail.com }}$ 
(92,1\%), sedangkan persentase persepsi terendah dimiliki mahasiswa Psikologi (72,2\%). Terjadi peningkatan persepsi dari mahasiswa tahun pertama $(85,7 \%)$ ke mahasiswa tahun kedua $(89,9 \%)$ dan kembali menurun pada mahasiswa tahun ketiga (76\%).

Kesimpulan: Persepsi mahasiswa FK UNAND berada dalam kategori baik. Tetapi kemampuan untuk memahami profesi lain masih kurang sehingga perlu menjadi hal yang perlu diperhatikan dan diperbaiki.

Kata kunci: kolaborasi, interprofessional education, persepsi, mahasiswa

\section{PRACTICE POINTS}

- Implementasi program IPE di setiap program studi sangat penting dalam membentuk kemampuan kolaborasi dan komunikasi dalam mempersiapkan mahasiswa memberikan layanan kesehatan secara optimal.

- Perlunya implementasi program IPE pada program studi Psikologi yang terintegrasi dalam kurikulum.

- Sistem pembelajaran kelompok menjadi media penting dalam membina kolaborasi dan komunikasi mahasiswa untuk bekerja secara interprofesi dalam melayani pasien di masa depan.

- Kegiatan belajar bersama antar program studi sangat diperlukan sebagai implementasi dari IPE dalam mengenali dan meningkatkan pemahaman mengenai tanggung jawab profesi lain.

\section{LATAR BELAKANG}

Problematika dalam kesehatan akhir-akhir ini menunjukkan arah yang dinamis. Saat ini, dunia kesehatan menghadapi masalah kesehatan ibu dan anak, minimnya sumber daya kesehatan, isu keselamatan pasien, dan peningkatan populasi usia lanjut yang menimbulkan pelayanan semakin kompleks. ${ }^{1}$ Penyelesaian masalah kesehatan pada era globalisasi membutuhkan pendekatan secara menyeluruh dan bersifat kolaborasi antar tenaga kesehatan. $^{2}$

Kolaborasi antar tenaga kesehatan yang tidak dilaksanakan dengan efektif menimbulkan dampak kurang baik dalam pelayanan kesehatan seperti minimnya komunikasi antar tenaga kesehatan, sehingga mengakibatkan penurunan kualitas perawatan kesehatan dan meningkatkan kejadian kesalahan medis (medical error). ${ }^{2}$ Berdasakan laporan Institute of Medicine (IOM), ${ }^{3}$ kesalahan medis telah menyebabkan 40.000-100.000 penduduk Amerika meninggal disusul dengan kealpaan dan komplikasi.

Pelaksanaan praktik kolaboratif antar tenaga kesehatan berdampak terhadap pelayanan kesehatan yang maksimal, menguatkan sistem kesehatan, dan meningkatkan outcomes kesehatan. ${ }^{3}$ Berdasarkan laporan Institute for Health Care Improvement (IHI), ${ }^{4}$ pengaplikasian praktik kolaborasi menunjukkan hasil signifikan berupa penurunan waktu tunggu pelayanan sebanyak $50 \%$, penurunan angka absensi pekerja sebanyak $25 \%$, penurunan biaya ICU sebesar $25 \%$, dan penurunan jumlah rawat inap untuk pasien dengan gagal jantung kongestif sebesar 50\%. Walaupun praktik kolaborasi memiliki dampak positif, dalam pelaksanaannya tenaga kesehatan belum melaksanakan praktik ini dengan maksimal. Beberapa faktor penyebabnya antara lain perbedaan status antar profesi, stereotip, paradigma superioritas, dan tindakan bersifat instruksi dari profesi lain. ${ }^{5}$

Dalam mewujudkan kolaborasi antar tenaga kesehatan, salah satu cara yang dapat dilakukan yaitu memperkenalkan praktik kolaborasi sejak dini melalui sistem pendidikan. Peningkatan kemampuan kolaborasi dapat diterapkan pada konsep pendidikan terpadu melalui Interprofessional Education (IPE). IPE merupakan proses interaksi dan kolaborasi antar dua atau lebih profesi kesehatan yang saling memahami tugas masing-masing dalam rangka meningkatkan derajat pelayanan kesehatan. ${ }^{6}$ Implementasi IPE 
pada setiap institusi pendidikan kedokteran merupakan sesuatu yang harus dilaksanakan mengingat kemampuan kolaborasi interprofesi merupakan keahlian yang harus dimiliki oleh dokter dan tercantum dalam Standar Kompetensi Dokter Indonesia (SKDI). ${ }^{7}$

IPE memiliki dampak positif dalam rangka peningkatan mutu pelayanan kesehatan seperti meningkatkan kepercayaan diri dalam tim, menambah wawasan pengetahuan, dan kompetensi dalam memanajemen individu. ${ }^{8}$ Hal tersebut menjadi solusi dalam rangka menekan angka kematian, jumlah komplikasi penyakit, lama rawat inap, dan konflik antar tenaga kesehatan. ${ }^{9}$ Keberhasilan pelaksanaan IPE dipengaruhi oleh berbagai faktor. Salah satu faktor yang terlibat dalam kesuksesan pelaksanaan IPE yaitu persepsi. Faktor persepsi yang baik dari mahasiswa dibutuhkan untuk mengawali dan memajukan konsep IPE dalam proses pembelajaran. $^{10}$

Penelitian mengenai persepsi mahasiswa terhadap IPE sudah dilakukan di Indonesia. Penelitian oleh A'la et al ${ }^{11}$ terhadap mahasiswa tahap akademik di Fakultas Kedokteran Universitas Gadjah Mada (FK UGM) menunjukkan 217 dari 250 (86,8\%) mahasiswa memiliki persepsi yang baik terhadap IPE. Penelitian oleh Hakiman et $\mathrm{al}^{12}$ menunjukkan hasil serupa dimana mahasiswa profesi kesehatan Universitas Padjadjaran (UNPAD) memiliki persepsi yang baik terhadap IPE sebesar 98\%. Penelitian yang dilakukan Ariyanti ${ }^{13}$ terhadap mahasiswa rumpun ilmu kesehatan di UNAND menunjukkan 86,36\% memiliki persepsi yang baik terhadap IPE. Sementara penelitian yang dilaksanakan oleh Silalahi et $\mathrm{al}^{14}$ terhadap Sekolah Tinggi Ilmu Kesehatan (STIKES) 'Aisyiyah Yogyakarta menunjukkan sebanyak 58 dari 65 mahasiswa memiliki persepsi yang cukup terhadap IPE.

Penelitian ini merupakan kelanjutan dari penelitian Riyanda pada tahun 2017. Perbedaan penelitian ini dengan penelitian sebelumnya adalah perubahan substansi kurikulum antara tahun 2014 dan 2019, letak perbedaan kurikulum ini adalah silabus pembelajaran, metode penilaian indikator angka dan mutu (learning asessment),
Berdasarkan uraian masalah di atas dan adanya perubahan kurikulum pembelajaran pada FK UNAND, maka diperlukan penelitian mengenai persepsi mahasiswa terhadap implementasi IPE. Penelitian ini telah lulus uji etik oleh Tim Komite Etik Fakultas Kedokteran Universitas Andalas dan memiliki ethical clearance dengan nomor 029/KEP/ $\mathrm{FK} / 2020$.

\section{METODE}

Jenis penelitian ini adalah deskriptif dengan rancangan cross-sectional. Penelitian dilakukan dari bulan November 2019 sampai Februari 2020 di FK UNAND, Padang. Penelitian ini melibatkan mahasiswa FK UNAND dari tiga program studi (prodi) yaitu kedokteran, psikologi, dan kebidanan pada mahasiswa tahun pertama (angkatan 2019) hingga mahasiswa tahun ketiga akademik (angkatan 2017).

Sampel penelitian dipilih dengan memenuhi kriteria inklusi dan kriteria eksklusi. Kriteria inklusi penelitian ini adalah: mahasiswa FK UNAND prodi kedokteran, psikologi, dan kebidanan tahun pertama hingga tahun ketiga akademik dan bersedia menjadi responden penelitian dengan mengisi lembar persetujuan responden. Teknik pengambilan sampel pada penelitian ini menggunakan teknik proportionate stratified random sampling yaitu mengambil secara acak dari setiap angkatan program studi di FK UNAND dengan memerhatikan jumlah mahasiswa setiap prodi dan angkatannya.

Data diperoleh dengan cara wawancara menggunakan kuesioner Interdisciplinary Education Perception Scale (IEPS). Kuesioner telah diterjemahkan ke Bahasa Indonesia oleh Fauziah ${ }^{15}$ untuk menentukan tingkatan persepsi pada mahasiswa profesi FK UGM yaitu baik, sedang, dan buruk. Kuesioner telah dilakukan uji validitas dan reliabilitas pada 30 mahasiswa tahap profesi FK UGM. Didapatkan uji validitas dengan nilai koefisisen 0,392 sampai 0,756, sementara hasil uji reliabilitas didiapatkan nilainya 0,887. Data jumlah mahasiswa diperoleh melalui bagian akademik FK UNAND.

Data dianalisis secara statistik menggunakan sistem komputerisasi yaitu analisis univariat. Analisis 
univariat dilakukan untuk melihat distribusi frekuensi data mengenai persepsi mahasiswa FK UNAND terhadap implementasi IPE.

\section{HASIL DAN PEMBAHASAN}

Penelitian ini dilakukan terhadap 300 orang mahasiswa FK UNAND sesuai dengan rumus sampel yang digunakan dengan taraf keyakinan 95\%. Responden penelitian terdiri atas 190 mahasiswa prodi kedokteran, 72 mahasiswa prodi psikologi, dan 38 mahasiswa prodi kebidanan. Penelitian ini melibatkan mahasiswa tahun pertama hingga tahun ketiga.

\section{Gambaran Persepsi Mahasiswa Fakultas Kedokteran UNAND terhadap Implementasi IPE Secara Umum}

Persepsi mahasiswa terhadap implementasi IPE secara umum diukur menggunakan kuesioner IEPS yang terdiri atas 18 butir pernyataan. Persepsi mahasiswa akan digolongkan menjadi tiga kategori, yaitu baik, sedang, dan buruk.

Tabel 1. Distribusi Frekuensi Persepsi Mahasiswa FK UNAND terhadap Implementasi IPE Secara Umum

\begin{tabular}{lrc|}
\multicolumn{1}{c}{ Persepsi } & N & $\%$ \\
\hline Baik & 252 & 84 \\
Sedang & 47 & 15,7 \\
Buruk & 1 & 0,3 \\
\multicolumn{1}{c}{ Total } & 300 & 100 \\
\hline
\end{tabular}

Secara umum mahasiswa FK UNAND memiliki persepsi yang baik terhadap implementasi IPE yaitu 252 orang (84\%). Hal serupa didapatkan pada penelitian Ariyanti ${ }^{13}$ yang menunjukkan tingkat persepsi baik terhadap IPE pada mahasiswa fakultas kesehatan tingkat akhir UNAND (86,36\%).

Menurut asumsi peneliti, munculnya persepsi baik terhadap implementasi IPE dapat disebabkan oleh berbagai faktor, seperti pelaksanaan kuliah IPE di FK UNAND yang telah diperkenalkan kepada mahasiswa sejak tahun pertama dan terintegrasi dalam kurikulum. Kurikulum tersebut akan berfokus terhadap pengembangan kemampuan komunikasi dan kolaborasi mahasiswa. Implementasi akan berjalan dengan maksimal jika mendapatkan dukungan dari seluruh elemen staf pengajar dan pimpinan institusi. Dengan komitmen dan dukungan yang ada membuat IPE terlaksana dengan optimal sehingga mahasiswa memiliki persepsi yang baik terhadap IPE.

IPE menjadikan setiap mahasiswa dari latar belakang profesi berbeda berinteraksi dan belajar bersama sehingga terjadi proses pertukaran ilmu dan kemampuan sebagai solusi dalam menyelesaikan permasalahan kesehatan yang ada. Persepsi yang baik terhadap IPE akan muncul ketika mahasiswa mampu beradaptasi dan belajat pada lingkungan yang melakukan praktik kolaborasi interprofesi. ${ }^{16}$

\section{Gambaran Persepsi Mahasiswa Fakultas Kedokteran UNAND terhadap Implementasi IPE Berdasarkan Komponen Persepsi}

Persepsi mahasiswa terhadap implementasi IPE terdiri atas empat komponen yaitu kompetensi dan autonomi, kebutuhan untuk bekerja sama, bukti bekerja sama, dan pemahaman mengenai profesi lain. Masing-masing komponen akan dilakukan penilaian sehingga dikategorikan menjadi baik, sedang, dan buruk.

\begin{tabular}{|c|c|c|c|c|c|c|}
\hline \multirow{2}{*}{$\begin{array}{l}\text { Komponen } \\
\text { Persepsi }\end{array}$} & \multicolumn{2}{|c|}{ Baik } & \multicolumn{2}{|c|}{ Sedang } & \multicolumn{2}{|c|}{ Buruk } \\
\hline & $\mathbf{N}$ & $\%$ & $\mathbf{N}$ & $\%$ & $\mathbf{N}$ & $\%$ \\
\hline $\begin{array}{l}\text { Kompetensi dan } \\
\text { autonomi }\end{array}$ & 260 & 86,7 & 39 & 13 & 1 & 0,3 \\
\hline $\begin{array}{l}\text { Kebutuhan } \\
\text { untuk bekerja } \\
\text { sama }\end{array}$ & 264 & 88 & 5 & 11,7 & 1 & 0,3 \\
\hline $\begin{array}{l}\text { Bukti bekerja } \\
\text { sama }\end{array}$ & 270 & 90 & 29 & 9,7 & 1 & 0,3 \\
\hline $\begin{array}{l}\text { Pemahaman } \\
\text { mengenai } \\
\text { profesi lain }\end{array}$ & 153 & 51 & 144 & 48 & 3 & 1 \\
\hline
\end{tabular}

Sebagian besar persepsi mahasiswa FK UNAND dalam kategori baik pada setiap komponen persepsi 
terhadap IPE. Berdasarkan empat komponen persepsi yang ada, komponen persepsi bukti bekerja sama memiliki nilai persepsi tertinggi (90\%). Hal sama juga ditunjukkan pada penelitian di Fakultas Kedokteran dan Ilmu Kesehatan Universtas Muhammadiyah Yogyakarta (FKIK UMY), ${ }^{17}$ bahwa komponen persepsi bukti bekerja sama memiliki persentase tertinggi di antara komponen persepsi lainnya (81\%).

Sistem pendidikan di FK UNAND menerapkan sistem belajar kelompok. Hal tersebut membantu setiap mahasiswa untuk membangun komunikasi dan kolaborasi antar sesama sehingga dapat menumbuhkan kerja sama dalam menyelesaikan masalah. Faktor lain yang memengaruhi adalah motivasi yang menjadi dasar penggerak bagi seseorang agar mau untuk melaksanakan setiap kewajiban sehingga mampu menerapkan komponen IPE termasuk bekerja sama antar profesi. Selain itu, faktor sikap juga memiliki peran dalam menentukan tercapainya komponen persepsi. Sikap erat kaitannya dengan penerimaan stimulus yang telah didapatkan berdasarkan hasil pengetahuan. Pengetahuan yang telah didapatkan sebelumnya menjadi dasar agar seseorang bersikap yang baik. Sikap mahasiswa yang baik terhadap kerja sama tim akan berdampak terhadap kolaborasi yang maksimal dalam pelayanan kesehatan. ${ }^{18}$ Hal-hal tersebut dapat menjadi faktor tingginya tingkat komponen persepsi bukti bekerja sama.

Praktik IPE dalam pelaksanaannya di tahap akademik harus berlandaskan kepada kompetensi inti. Kompetensi inti tersebut dirancang oleh Interprofessional Education Collaborative (IPEC) yang salah satunya adalah kerja sama tim. ${ }^{19}$ Hasil penelitian di atas mendeskripsikan kerja sama tim antar profesi kesehatan akan berjalan lebih optimal jika IPE dilaksanakan pada mahasiswa yang terintegrasi sebagai bagian dari kurikulum pembelajaran. Kerja sama tim yang maksimal dalam melayani dan mewujudkan rasa puas terhadap pasien timbul dikarenakan adanya persepsi yang baik pada IPE. ${ }^{20}$

Komponen persepsi pemahaman mengenai profesi lain memiliki nilai persepsi dengan persentase terendah (51\%). Hal ini sejalan dengan penelitian Riyanda $^{9}$ yang didapatkan komponen persepsi pemahaman mengenai profesi lain memiliki persentase terendah dibandingkan dengan tiga komponen persepsi lainnya (60,7\%). Belum terdapatnya pengkajian tentang wewenang, tanggung jawab, dan cakupan peran antar profesi pada tahap akademik menyebabkan pemahaman mengenai profesi lain menjadi minim sehingga pemahaman terhadap profesi lain hanya dibentuk dari masingmasing individu. ${ }^{21}$

\section{Gambaran Persepsi Mahasiswa Fakultas}

Kedokteran UNAND terhadap Implementasi IPE Berdasarkan Program Studi

Persepsi diukur menggunakan kuesioner IEPS dan dikelompokkan menjadi baik, sedang, dan buruk.

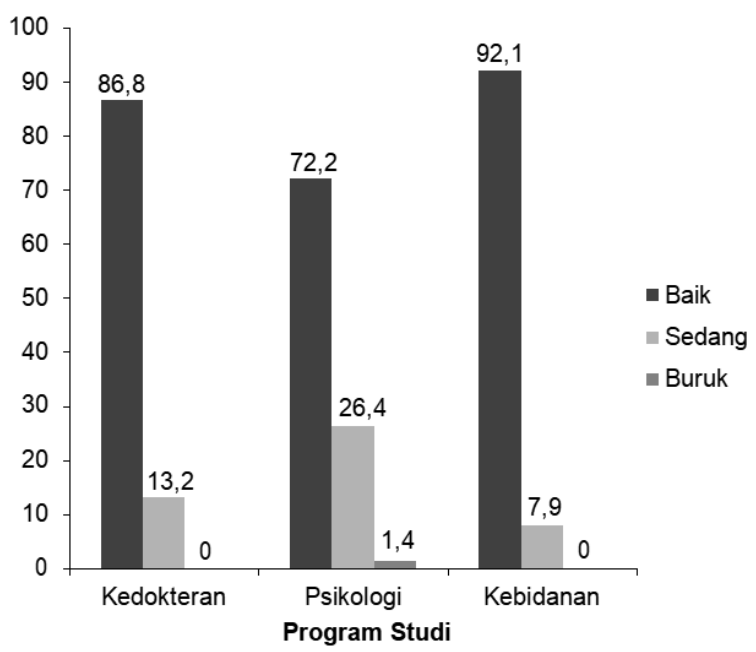

Gambar 1. Distribusi Frekuensi Persepsi Mahasiswa FK UNAND terhadap Implementasi IPE Berdasarkan Program Studi

Sebanyak 35 mahasiswa prodi kebidanan $(92,1 \%)$ memiliki persepsi yang baik terhadap implementasi IPE. Hal ini serupa dengan penelitian Riyanda ${ }^{9}$ yaitu mahasiswa kebidanan memiliki persepsi yang baik terhadap IPE $(87,2 \%)$. Sementara itu, sebanyak 65 mahasiswa prodi kedokteran $(86,8 \%)$ memiliki persepsi yang baik terhadap implementasi IPE. Hasil yang sama juga ditunjukkan pada penelitian yang dilakukan Sundari et al, ${ }^{22}$ dimana mahasiswa prodi pendidikan dokter memiliki persepsi yang baik terhadap IPE (78,3\%). 
Peneliti berpendapat tingginya persentase persepsi pada prodi kebidanan dan kedokteran dipengaruhi oleh beberapa faktor. Salah satunya adalah sistem belajar kelompok yang diterapkan pada proses pembelajaran. Kegiatan seperti keterampilan klinik dan tutorial mampu menjadi wadah dalam berinteraksi dan berkomunikasi serta memecahkan masalah (problem solving). Diskusi yang dilakukan berguna sebagai landasan untuk membentuk mahasiswa yang bekerja sama secara interprofesi dalam memberikan pelayanan kesehatan secara optimal kepada pasien nantinya.

Program IPE menjadi wadah mahasiswa dalam mengembangkan kerja sama, komunikasi, dan berdiskusi dalam tim. Dalam merancang program pembelajaran IPE perlu diperhatikan tingkat pemahaman kolaborasi interprofesi dan persepsi mahasiswa agar kemampuan yang dilatih dapat diterapkan dengan baik..$^{23}$ Penerapan IPE sangat membantu untuk mengurangi kesalahan medis dalam pelayanan kesehatan dan meningkatkan keselamatan pasien. ${ }^{24}$

Mahasiswa prodi psikologi secara umum memiliki persepsi yang baik terhadap implementasi IPE $(72,2 \%)$. Hasil serupa juga ditunjukkan pada penelitian yang dilakukan Roberts et $\mathrm{al}^{25}$ yang menyatakan mahasiswa psikologi di Australian University memiliki sikap yang positif terhadap IPE (62\%). Prodi psikologi memiliki persentase persepsi terhadap implementasi IPE terendah dibandingkan dengan prodi lainnya di FK UNAND. Hal tersebut dikarenakan prodi psikologi belum memasukkan IPE dalam kurikulum. Prodi psikologi masih menggunakan kurikulum konvensional sehingga menyebabkan keterbatasan dalam mengaplikasikan program IPE. Mahasiswa hanya dapat merasakan dampak IPE secara nyata jika memiliki rencana karir dalam pelayanan kesehatan terhadap pasien dan pengaturan sistem kesehatan. Faktor ini memengaruhi tingkat persepsi mahasiswa psikologi terhadap IPE. ${ }^{26}$ Belum maksimalnya pengenalan kurikulum IPE pada prodi psikologi berdampak terhadap tingkat persepsi yang lebih rendah jika dibandingkan dengan prodi kedokteran dan kebidanan yang sudah terlebih dahulu menerapkannya. Pengenalan sistem IPE pada sistem pembelajaran dinilai penting dalam menumbuhkan persepsi yang baik pada mahasiswa. ${ }^{14}$

\section{Gambaran Persepsi Mahasiswa Fakultas}

Kedokteran UNAND terhadap Implementasi IPE Berdasarkan Tahun Akademik

Pengukuran persepsi mahasiswa terhadap implementasi IPE dilakukan pada masingmasing mahasiswa tahun pertama, kedua, dan ketiga. Pengukuran menggunakan kuesioner IEPS dan dilakukan penilaian sehingga persepsi dikelompokkan menjadi baik, sedang, dan buruk.

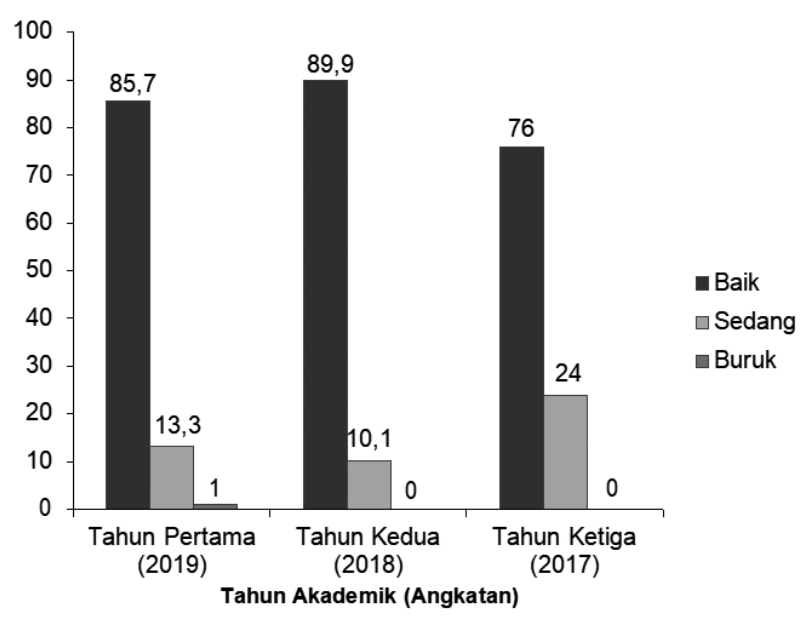

Gambar 2. Distribusi Frekuensi Persepsi Mahasiswa FK UNAND terhadap Implementasi IPE Berdasarkan Tahun Akademik

Sebagian besar mahasiswa pada masing-masing angkatan memiliki persepsi yang baik terhadap implementasi IPE, yakni tahun kedua sebanyak 89 orang $(89,9 \%)$, tahun pertama sebanyak 90 orang $(85,7 \%)$, dan tahun ketiga sebanyak 73 orang $(76 \%)$. Menurut Williams et $\mathrm{al}^{26}$ mahasiswa mempunyai ketertarikan yang tinggi terhadap pembelajaran IPE pada tahap awal pendidikan dan akan menurun ketika mahasiswa mendekati masa akhir pendidikan.

Menurut pendapat peneliti, faktor yang memengaruhi tingginya persentase persepsi mahasiswa tahun kedua dibandingkan tahun pertama dikarenakan mahasiswa tahun pertama baru memperoleh materi IPE dan belum banyak berinteraksi dengan mahasiswa 
seangkatan dan mahasiswa senior. Sedangkan mahasiswa tahun kedua telah mendapatkan materi tentang IPE. Kegiatan ekstrakurikuler yang diikuti mahasiswa berperan dalam meningkatkan kemampuan kognitif dan afektif mahasiswa, serta membuat mahasiswa lebih terampil, berkarakter, dan berprestasi. Salah satu keterampilan yang dapat dilatih adalah kemampuan komunikasi dan kerja sama tim. Pengalaman yang dimiliki oleh mahasiswa dengan mengikuti kegiatan ekstrakurikuler memberikan dampak positif terhadap pembentukan persepsi mahasiswa yang baik terhadap implementasi IPE dan menjadi bekal yang bagus dalam rangka meningkatkan perawatan terhadap pasien. ${ }^{27} \mathrm{Hal}$ ini sesuai dengan tujuan dan manfaat IPE yang memberikan kesempatan kepada mahasiswa untuk berkomunikasi dan berkolaborasi hingga mampu menjadi tim kesehatan yang memberikan pelayanan kesehatan maksimal kedepannya. ${ }^{28}$
Gambaran Persepsi Mahasiswa Fakultas Kedokteran UNAND terhadap Implementasi IPE Berdasarkan Komponen Persepsi pada Setiap Program Studi

Mahasiswa prodi kedokteran memiliki persepsi yang baik terhadap semua komponen persepsi dengan persentase tertinggi $(92,6 \%)$ yaitu komponen persepsi kompetensi dan autonomi. Komponen persepsi pemahaman mengenai profesi lain memilki persentase terendah (53,7\%). Penelitian yang dilakukan oleh Riyanda ${ }^{10}$ menunjukkan hasil serupa yaitu komponen persepsi kompetensi dan autonomi memiliki persepsi tertinggi di antara prodi lainnya (83\%). Setiap profesi diberikan wewenang untuk mengatur dan mengurus segala hal yang ada di dalam profesinya. Hasil persepsi ini menunjukkan mahasiswa prodi kedokteran sudah memiliki landasan untuk melaksanakan praktik kolaborasi dalam memberikan pelayanan kesehatan.

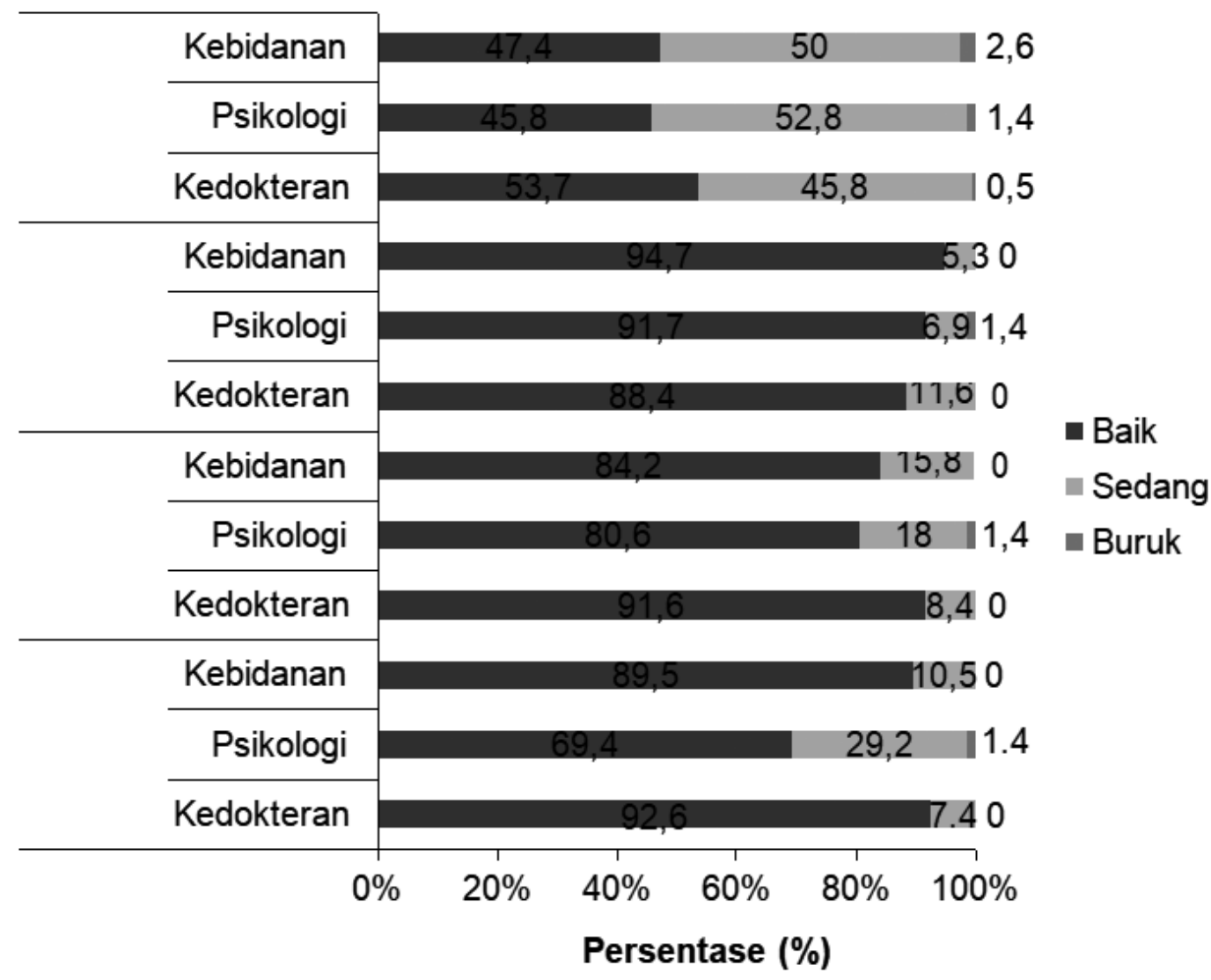

Gambar 3. Distribusi Frekuensi Persepsi Mahasiswa FK UNAND terhadap Implementasi IPE Berdasarkan Komponen Persepsi pada Setiap Program Studi 
Secara umum mahasiswa prodi psikologi memiliki persepsi yang baik terhadap semua komponen persepsi dengan persentase tertinggi pada komponen bukti untuk bekerja sama (91,7\%). Komponen persepsi pemahaman mengenai profesi lain memiliki persentase terendah $(45,8 \%)$.

Mahasiswa prodi kebidanan memiliki persepsi yang baik terhadap keempat komponen persepsi dengan persentase tertinggi yaitu komponen bukti bekerja sama (94,7\%). Komponen persepsi pemahaman mengenai profesi lain memiliki persentase terendah (47,4\%). Menurut Murray-Davis et al $^{29}$, bidan mempunyai pandangan positif terhadap IPE. Namun sebagian besar bidan memerlukan profesi lain dalam memahami tugas dan tanggung jawab profesi mereka.

Komponen persepsi pemahaman mahasiswa terhadap profesi lain pada ketiga prodi memiliki persentase terendah dibandingkan komponen lainnya. Belum tingginya tingkat pemahaman mahasiswa terhadap profesi lain pada ketiga prodi dikarenakan minimnya interaksi dan komunikasi interprofesi. Hal ini dapat dilihat dari partisipasi mahasiswa ketiga prodi pada semua UKM tingkat fakultas. Tidak semua program studi terlibat dalam semua UKM, bahkan prodi psikologi hanya bisa terlibat dalam lima dari sepuluh UKM. Sementara prodi kedokteran dan kebidanan mampu terlibat dalam semua UKM sehingga pengembangan IPElebih maksimal. Derajat pelayanan kesehatan sangat dipengaruhi oleh kemampuan kolaborasi, komunikasi, dan kerjasama antar tenaga kesehatan. Sejatinya kemampuan tersebut dapat dikembangkan dengan mengimplementasikan IPE pada tahap akademik sehingga terbentuk rasa saling memahami dan menghargai antar tenaga kesehatan kedepannya. $^{30}$

Dalam penelitian terdapat beberapa keterbatasan berupa kemungkinan terjadinya bias dalam memberikan jawaban kuesioner, karena pengisian kuesioner dilakukan tergesa-gesa dan tidak sesuai dengan kejujuran responden.

\section{KESIMPULAN}

Berdasarkan hasil penelitian ini didapatkan kesimpulan bahwa secara umum persepsi mahasiswa
FK UNAND terhadap implementasi IPE berada dalam kategori baik dengan persentase tertinggi pada komponen persepsi bukti bekerja sama. Mahasiswa prodi kedokteran, psikologi, dan kebidanan memiliki persepsi yang baik tehadap implementasi IPE dengan persentase tertinggi pada prodi kedokteran yaitu komponen persepsi kompetensi dan autonomi, sementara pada prodi psikologi dan kebidanan yaitu komponen persepsi bukti bekerja sama. Mahasiswa tahun kedua memiliki persepsi yang baik terhadap implementasi IPE dibandingkan mahasiswa tahun pertama dan ketiga akademik. Komponen persepsi pemahaman mahasiswa terhadap profesi lain pada ketiga prodi memiliki persentase terendah dibandingkan komponen lainnya.

\section{SARAN}

Diperlukannya pelaksanaan kuliah multidisplin mahasiswa FK UNAND guna memberikan kesempatan kepada mahasiswa dalam meningkatkan kemampuan komunikasi dan kolaborasi. Selain itu pentingnya pelaksanaan workshop terhadap dosen secara berkelanjutan dalam meningkatkan kompetensi dan menemukan inovasi dalam pelaksanaan IPE kepada mahasiswa.

\section{UCAPAN TERIMA KASIH}

Terima kasih kepada semua pihak yang telah membantu dalam pelaksanaan penelitian. Kepada Pimpinan FK UNAND yang telah memberikan izin melaksanakan penelitian dan kepada seluruh mahasiswa FK UNAND angkatan 2017 sampai 2019 yang telah bersedia menjadi responden penelitian.

\section{DEKLARASI KEPENTINGAN}

Para penulis mendeklarasikan bahwa tidak terdapat konflik kepentingan apapun terkait studi pada naskah ini.

\section{DAFTAR SINGKATAN}
FK UGM : Fakultas Kedokteran Universitas Gadjah Mada

FK UNAND: Fakultas Kedokteran Universitas Andalas 
FK UNPAD : Fakultas Kedokteran Universitas Padjadjaran

FKIK UMY : Fakultas Kedokteran dan Ilmu Kesehatan Universitas Muhammadiyah Yogyakarta

IEPS : Interdisciplinary Education Perception Scale

IHI : Institute of Health Care Improvement

IOM : Institute of Medicine

IPE : Interprofessional Education

IPEC : Interprofessional Education Collaborative

Prodi : Program studi

SKDI : Standar Kompetensi Dokter Indonesia

STIKES : Sekolah Tinggi Ilmu Kesehatan

UKM : Unit Kegiatan Mahasiswa

\section{KONTRIBUSI PENULIS}

Multazam Fahreza Chandra - berkontribusi sebagaipeneliti utama, menyusun proposal penelitian, mengumpulkan data, dan analis data utama, dan penulis naskah.

Laila Isrona - berkontribusi sebagai pembimbing dalam penyusunan proposal dan pelaksanaan penelitian serta meninjau naskah publikasi.

Emilzon Taslim - berkontribusi sebagai pembimbing dalam penyusunan proposal dan meninjau naskah publikasi.

Ilmiawati - berkontribusi dalam meninjau naskah publikasi.

\section{DAFTAR PUSTAKA}

1. Drynan D, Murphy S. Understanding and Faciliting Interprofessional Education. $2^{\text {nd }}$ ed. Vancouver: Faculty of Medicine University of British Columbia; 2013. p.6

2. Kristina TN, Sudaryanto, Asmara FY, Nuryanto, Wirakusumah F, Syukiani Y. CommunityBased Health-Professions Interprofessional Education: A

3. Collaborative and Sustainable Model. Jurnal Pendidikan Kedokteran Indonesia. 2018;7(1):3643.
4. Institute of Medicine (IOM). Measuring the Impact of Interprofessional Education (IPE) on Collaborative Practice and Patient Outcomes. Washington DC. National Academies Press; 2015. p.3-30.

5. Institute for Healthcare Improvement (IHI). The breakthrough series: IHI's collaborative model for achieving breakthrough improvement. Cambridge; 2003. p.1.

6. Legare F, Stacey D, Gagnon S, Dunn S, Pluye P, Frosch D, et al. Validating a Conceptual Model for an Inter-professional Approach to Shared Decision Making: A Mixed Methods Study. Journal of Evaluation for Clinical Practice. 2011:562.

7. HPEQ-Project DIKTI. Apa kata mahasiswa? Hasil kajian partisipasi \& kolaborasi mahasiswa kesehatan di Indonesia [document on internet]. Kementerian Pendidikan dan Kebudayaan Republik Indonesia; 2011 [cited 14 Oktober 2019]. Available from:

8. https://www.academia.edu/8878420/ Hasil_Kajian_Partisipasi_and_Kolaborasi_ Mahasiswa_Kesehatan_di_Indonesia

9. Muktamiroh H, Irmarahayu A, Setyaningsih Y. Recommendations of the Development of Interprofessional Education in a Faculty of Medicine. Jurnal Pendidikan Kedokteran Indonesia. 2019;8(2):97-104.

10. Darlow B, Coleman K, McKinlay E, Donnovan S, Beckingsale L, Gray B, et al. The Positive Impact of Interprofessional Education: A Controlled Trial to Evaluate a Programme for Health Professional Student. BMC Medical Education. 2015;15(98):6.

11. Frenk J, Chen L, Bhutta ZA, Cohen J, Crisp $\mathrm{N}$, Evans $\mathrm{T}$, et al. Health Professionals for a New Century: Transforming Education to Strengthen Health Systems in an Interdependent World. Journal of the Lancet. 2010;376(9756):1923-58.

12. Riyanda F. Gambaran Persepsi Mahasiswa Tahap Akademik Fakultas Kedokteran Universitas Andalas terhadap Interprofessional Education 
[skripsi]. Padang: Fakultas Kedokteran Universitas Andalas; 2017.

13. A’la MZ, Sedyowinarso M, Harjanto T, Kristan MS. Persepsi dan Kesiapan Mahasiswa Tahap Akademik terhadap Interprofessional Education di Fakultas Kedokteran Universitas Gadjah Mada. The Indonesian Journal of Health Science. 2012;2(2):187.

14. Hakiman APA, Dewi SP, Sayusman C, Wahyudi K. Persepsi Mahasiswa Profesi Kesehatan Universitas Padjajaran terhadap Interprofesionalism Education. Jurnal Sistem Kesehatan. 2016;1(4):209.

15. Ariyanti F. Gambaran Pengetahuan, Persepsi, dan Kesiapan Mahasiswa Ilmu Kesehatan Tingkat Akhir Mengenai Interprofessional Education di Universitas Andalas Padang tahun 2016 [skripsi]. Padang: Fakultas Kesehatan Masyarakat Universitas Andalas; 2016.

16. Silalahi V, Annisa DN, Handayani DS, Hinonaung JSH, Aini SN, Yanti ST, et al. Hubungan Persepsi Mahasiswa dengan Kesiapan STIKES 'Aisyiyah Yogyakarta terhadap Pelaksanaan Interprofessional Education (IPE). Jurnal Penelitian Kesehatan. 2017;4(2):87.

17. Fauziah FA. Analisis Gambaran Persepsi dan Kesiapan Mahasiswa Profesi FK UGM terhadap Interprofessional Education di Tatanan Pendidikan Klinik [skripsi]. Yogyakarta: Fakultas Kedokteran Universitas Gadjah Mada; 2010.

18. Ateah CA, Snow W, Wener P, MacDonald L, Metge C, Davis P, et al. Stereotyping as a Barrier to Collaboration: Does Interprofessional Education Make a Difference. Journal of Nurse Education Today. 2011;31:208-13.

19. Orbayinah S, Utami LP. Students' Perception of Interprofessional Education. International Journal of Public Health Science. 2015;4(4):28487.

20. Notoatmodjo S. Pendidikan dan Perilaku Kesehatan. Jakarta: Rineka Cipta; 2011. h.34-56.

21. Interprofessional Education Collaborative (IPEC). Core Competencies for Interprofessional Collaborative Practice: 2016 update. Washington
DC: Interprofessional Education Collaborative; 2016. p.9-14.

22. Fallatah HI, Jabbad R, Fallatah HK. Interprofessional Education as a Need: The Perception of Medical, Nursing Students and Graduates of Medical College at King Abdulaziz University. Journal of Scientific Research Publishing. 2015;6:248- 54 .

23. Honan L, Fahs DB, Talwalkar JS, Kayingo G. Interprofessional Learning: Perception of First Year Health Students. Journal of Nursing Education and Practice. 2015;5(6):39-49.

24. Sundari S, Sembodo A. Perbedaan Persepsi Mahasiswa Tahap Profesi di FKIK UMY tentang Interprofessional Education di Asri Medical Center Yogyakarta. Journal of Medical Education 2014:3.

25. Pamungkasari EP, Probandari A, Randita ABT, Parwatiningsih SA. Students' and Academic Staffs' Perspectives on an Interprofessional Education Model. The Indonesian Journal of Medical Education. 2018;7(3):197-205.

26. Anwar H, Rosa EM. Meningkatkan Komunikasi dan Kolaborasi dengan Interprofessional Education (IPE): Literatur Review. Jurnal Keperawatan Muhammadiyah. 2019: 91-101.

27. Roberts LD, Forman D. Interprofessional Education for First Year Psychology Students: Career Plans, Perceived Relevance and Attitudes. Journal of Interprofessional Care. 2015;29(3):188-94.

28. Williams B, Brown T, McKenna L, Palermo C, Morgan P, Brithwell R. Students' Attitude Toward Interprofessional Learning: A Comparison Between Two Universities. Journal of Allied Health. 2015;44(4):201-7.

29. Montelongo R. Student participation in college student organization: A review of literature. Journal of the Indians University Student Personnel Association. 2002: 50-63.

30. Fakultas Kedokteran Unversitas Gadjah Mada. Buku Acuan Umum CHFC-IPE. Yogyakarta: Fakultas Kedokteran Unversitas Gadjah Mada; 2014. h.21-2. 
31. Murray-Davis B, Marshall M, Gordon F. What do Midwives Think about Interprofessional Working and Learning? Journal of Midwifery. 2011;27(3):376-81.
32. Patricia J, Bakri S, Adespin DA. Gambaran Persepsi dan Kesiapan Dosen Fakultas Kedokteran Universitas Diponegoro terhadap Interprofessional Education (IPE). Jurnal Kedokteran Diponegoro. 2019;8(2):735-46. 